ДОСЛІДЖЕННЯ СТАНУ СОЦІАЛЬНО-ПСИХОЛОГІЧНОГО КЛІМАТУ НАУКОВО-ПЕДАГОГІЧНОГО КОЛЕКТИВУ: ПРАКТИЧНИЙ АСПЕКТ

\title{
STUDYING THE STATE OF SOCIO-PSYCHOLOGICAL CLIMATE PEDAGOGICAL TEAM: PRACTICAL ASPECT
}

Стаття присвячена одній з актуальних проблем психології управління-соціально-психологічному клімату педагогічного колективу, підтриманню та покращенню клімату засобами впливу керівника крізь призму стилю керівництва. Зокрема, розкривається сутність поняття «соціально-психологічний клімат», що відображає якісний бік міжособистісних відносин членів колективу та стиль керівниитва. Дослідники одностайні лише у розумінні соціально-психологічного клімату як складного багатокомпонентного феномену, аналіз якого потребує комплексного системного підходу. Соціальнопсихологічний клімат колективу визначено як відображення характеру взаємовідносин між людьми, тон суспільного настрою в колективі, що переважає, задоволеність умовами життєдіяльності, стилем і рівнем управління та іншими чинниками.

Виділяють три типи соціально-психологічного клімату - сприятливий, нейтральний та несприятливий. Стиль керівництва, відносини між членами колективу є одними 3 найголовніших чинників, що впливають на якість та продуктивність праці та взаємини між членами колективу. Зосереджується увага на теоретичних засадах орормування та підтримання сприятливого соціально-психологічного клімату та діагностичних методиках визначення стану клімату та стилю керівництва.

Висвітлюються результати діагностики стану соціально-психологічного клімату. Результати дослідження довели взаємозв'язок стилю керівництва та стану соціально-психологічного клімату колективу. Зарезультатами діагностики встановлено, що науково-педагогічний колектив кафедри, що досліджувався, є сорормованим, але має певні прогалини у взаємостосунках членів колективу. У зв'язку з цим керівнику необхідно створити умови для зближення членів науково-педагогічного колективу кафедри. Зазначається, що перспектива подальшого дослідження передбачає розробку практичних рекомендацій керівникам структурних підрозділів закладу вищої освіти щодо формування та підтримання сприятливого клімату науково-педагогічного колективу.

Ключові слова: заклад вищої освіти, управління, керівник, стиль, соціально-психо- логічний клімат, діагностичні методики, результати.

The article is devoted to one of the topical problems of management psychology - the sociopsychological climate of the teaching staff, maintaining and improving the climate through the influence of the leader through the prism of leadership style. In particular, the essence of the concepts of socio-psychological climate is revealed, reflecting the qualitative side of the interpersonal relations of the team members and leadership style. Researchers are unanimous only in understanding the socio-psychological climate as a complex multicomponent phenomenon, the analysis of which requires a comprehensive systematic approach. In the article, the social and psychological climate of the collective is defined as a reflection of the nature of the relationship between people, the tone of the prevailing social mood in the team, satisfaction with living conditions, style and level of management and other factors. There are three types of socio-psychological climate - favorable, neutral and unfavorable. Leadership style, relationships between team members are some of the most important factors that affect the quality and productivity of work and relationships between team members. Focuses on the theoretical principles of the formation and maintenance of a favorable socio-psychological climate and diagnostic methods for determining the climate and leadership style. The results of diagnostics of the state of social and psychological climate are covered.

The results of the study proved the relationship between leadership style and the social and psychological climate of the team. According to the results of the research, it is established that the scientific-pedagogical team is formed, but has some gaps in the relationship of the members of the team. Therefore, the manager should create conditions for rapprochement of the members of the scientific-pedagogical team.

It is noted that the prospect of further research is to develop practical recommendations for the heads of structural units of the institution of higher education on the formation and maintenance of a favorable climate of the scientific and pedagogical team.

Key words: institution of higher education, management, manager, style, socio-psychological climate, diagnostic methods, results. імені К.Д. Ушинського»

Постановка проблеми в загальному вигляді. Система вищої освіти України впевнено інтегрується до європейського освітнього простору, де якість вищої освіти є визначальним чинником визнання і конкурентоспроможності вищого закладу освіти [13].

Реформація системи освіти, процеси ії модернізації, втілення концепції «Нова Українська школа», Закону України «Про освіту» підвищують вимоги до ефективності професійної діяльності педагогів, завданням яких є гармонійний розвиток, виховання і соціалізація особистості, здатної до самоосвіти та саморозвитку, життя в суспільстві та цивілізованої взаємодії з природою, з прагненням до самовдосконалення і навчання впродовж життя, готової до свідомого життєвого вибору та самореалізації, відповідальності, трудової діяльності й громадянської активності.

Науково-педагогічний колектив закладу вищої освіти має системну організацію і складає органічну частину всієї структури комплексного менеджменту освітньої діяльності, тому суттєвого значення набуває соціально-психологічний клімат, як системотворча структура колективу, успішне 
становлення якого залежить від керівника та його стилю керівництва.

Це зумовлює необхідність пошуку та забезпечення чинників, що мають вплив на ефективність і результативність професійної діяльності педагогів, серед яких особливу увагу науковці сорери психології управління приділяють соціально-психологічному клімату педагогічного колективу.

Наразі проблема фрормування та розвитку науково-педагогічного колективу закладу вищої освіти, як особливого виду людських взаємин, набула актуальності. Педагогічний колектив характеризується безпосередніми людськими стосунками, постійною напруженістю роботи, соціальною вразливістю та комунікативною активністю, визначенням умов оптимізації соціально-психологічного клімату у педагогічному колективі, підтриманням та покращенням клімату в колективі засобами впливу керівника крізь призму стилю керівництва [5, с. 133].

Аналіз останніх досліджень і публікацій. Публікації, у яких досліджувалось питання фрормування позитивного (сприятливого) соціальнопсихологічного клімату колективу, знайшло відображення у працях зарубіжних учених, серед яких М. Барлінгейм, Р. Болуіс, Д. Гобкінз, Є. Маккі та інші.

Феномен соціально-психолоігчного впливу досліджували російські та українські науковці Н. Анікеєва, В. Богданов, В. Бойко, С. Висоцький, А. Жакогян, О. Засурцева, Л. Зорін, Л. Карамушка, О. Ковальов, Н. Коломінський, Б. Лебедєв, В. Леонтьєв, Г. Ложкін, А. Лутошкін, Н. Мансуров, Г. Моченова, М. Ночевнік, В. Остряков, С. Папов'ян, В. Панфьоров, Б. Паригін, В. Семенов, Ю. Сировецький, І. Чорнобровкін, Л. Шубіна та інші.

Виділення не вирішених раніше частин загальної проблеми. Вплив соціально-психологічного клімату колективу на продуктивність та якість діяльності, на ефективність функціонування колективу, як психологічний френомен, досліджувався в трудових, виробничих та наукових колективах.

Н. Мансуров, який досліджував виробничі колективи, вперше використав термін «психологічний клімат», під яким розумів стан групової психіки, обумовлений особливостями життєдіяльності цієї групи, своєрідний сплав емоційного та інтелектуального фракторів: установок, відносин, настроїв, почуттів, думок членів групи [11, с. 245].

Психологічний клімат, як соціально-психологічне явище виробничого колективу, досліджували Ф. Джафрарова, А. Жамкочана, Т. Загрузіна, О. Засурцева, Л. Зоріна, Б. Махмудова, Г. Скомаровський, І. Чорнобровкін та інші.

Дослідженням проблеми психологічного клімату в педагогічному колективі займались Н. Анікеєва [2], Н. Коломінський [5], Л. Карамушка [7], В. Семиченко [14], Р. Шакурова [16]. Окремі аспекти соціально-психологічного клімату педагогічного колективу розглянуто у працях Г. Виноградова (морально-психологічний клімат у педагогічному колективі як чинник становлення майстерності вчителя), Є. Єрмолаєва (вплив стилю керівництва директора на соціально-психологічну атмосореру в педагогічному колективі), О. Мешко (підготовка майбутніх психологів до створення психологічного клімату в педагогічному колективі) [9].

Прослідковуються певні розбіжності між розумінням змісту і структури соціально-психологічного клімату. Конкретизації потребують питання чинників, форм і методів фрормування соціально-психологічного клімату. Важливим та актуальним залишається питання впливу управлінської діяльності керівників закладів вищої освіти на формування та підтримання сприятливого соціально-психологічного клімату науково-педагогічного колективу.

Мета статті. Зважаючи на актуальність проблеми фрормування та підтримання сприятливого соціально-психологічного клімату науковопедагогічного колективу закладу вищої освіти, метою статті $€$ аналіз результатів діагностики стану соціально-психологічного клімату науковопедагогічного колективу однієї 3 кафедр Вінницького державного педагогічного університету ім. М. Коцюбинського та вплив на нього стилю управлінської діяльності керівника.

Виклад основного матеріалу. Проблема фрормування сприятливого соціально-психологічного клімату в трудовому колективі розглядається як одна 3 найважливіших характеристик його діяльності. $€$ багато різних підходів до тлумачення поняття «соціально-психологічний клімат». Так, на думку Л. Корольова, соціально-психологічний клімат колективу відображає характер взаємовідносин між людьми, тон суспільного настрою в колективі, що переважає, задоволеність умовами життєдіяльності, стилем і рівнем управління та іншими чинниками. Отже, науковець розуміє соціально-психологічний клімат як стиль взаємовідносин і як настрій групи.

Питання формування психологічного клімату розглядалось у працях багатьох зарубіжних і вітчизняних науковців, однак слід зазначити, що у психології немає одностайності в трактуванні змісту, сутності, структури та інших аспектів цього феномену. Дослідники одностайні лише у тому, що це складний багатокомпонентний феномен, аналіз якого потребує комплексного системного підходу.

Виділяють три типи соціально-психологічного клімату - сприятливий, нейтральний та несприятливий [10]. У зв'язку з цим однією з важливих фрункцій керівника $є$ створення коморортного, здорового соціально-психологічного клімату в колективі. Головними ознаками сприятливого соціально-психологічного клімату є взаємна довіра між членами колективу і єдина мета; відсутність тиску керівни- 
ків і визнання за ними права приймати значущі для групи рішення. До нейтрального соціально-психологічного клімату належить колектив, який не має чіткої спрямованості, єдиної мети та чітко встановлених способів діяльності. Колектив з несприятливим соціально-психологічним кліматом характеризує негативна спрямованість, низька ефективність праці та висока плинність кадрів.

Основними чинниками, що впливають на стан соціально-психологічного клімату колективу, $\epsilon$ робота в цілому, стан устаткування, рівномірність забезпечення роботою, розмір заробітної плати, санітарно-гігієнічні умови, відносини з безпосереднім керівником, можливість підвищення кваліфрікації, різноманітність роботи та рівень її організації, ступінь впливу керівника на справи в колективі.

Соціально-психологічний клімат має безпосередній вплив на всі складники управлінської діяльності - вироблення і прийняття управлінських рішень, організацію їх виконання, облік та контроль [18, с. 21].

У зв'язку зі стрімким реформуванням освіти, зростанням вимог ринку праці, встановлення європейських стандартів якості освіти, посилен- ням конкуренції на ринку освітніх послуг зазнають адаптативних змін і стилі управління керівників закладу освіти. Д. Голманом виділено шість стилів керівництва: диктаторський, авторитетний, батьківський, демократичний, еталонний, наставницький. Кожен зі стилів має специфічний вплив на стан соціально-психологічного клімату колективу [1].

3 метою визначення впливу стилю керівництва на стан соціально-психологічного клімату науково-педагогічного колективу однієї 3 кафедр Вінницького державного педагогічного університету ім. М. Коцюбинського проведено діагностику за методикою $€$. Рогова «Загальна оцінка психологічного клімату колективу» та тестом Л. Почебут «Пульсар» $[12,15]$.

У дослідженні взяли участь 20 реципієнтів: науково-педагогічний колектив кафедри, 3 яких 10 опитуваних мають стаж роботи на кафредрі понад 10 років, 7 працівників зі стажем понад 5 років, 3 - менше 4 років.

Методика «Загальна оцінка психологічного клімату колективу» спрямована на виявлення особливостей відображення членами колективу сформованих міжособистісних відносин і колективу

Таблиця 1

Результати діагностики «Загальна оцінка психологічного клімату колективу» (Є. Рогова)

\begin{tabular}{|c|c|c|c|c|}
\hline \multicolumn{5}{|c|}{ Емоційний компонент } \\
\hline $\begin{array}{c}\text { № } \\
\text { питання }\end{array}$ & Питання & $\begin{array}{l}\text { Позитивна } \\
\text { оцінка }\end{array}$ & $\begin{array}{l}\text { Невизначена } \\
\text { оцінка }\end{array}$ & $\begin{array}{l}\text { Негативна } \\
\text { оцінка }\end{array}$ \\
\hline 6. & $\begin{array}{l}\text { Визначте, з яким із наведених тверджень Ви най- } \\
\text { більше згодні. }\end{array}$ & 13 & 7 & \\
\hline 8. & $\begin{array}{l}\text { Цифрра «1» характеризує колектив, що Вам дуже подо- } \\
\text { бається, а «9» - колектив, що Вам не подобається. }\end{array}$ & 19 & 1 & \\
\hline 12. & $\begin{array}{l}\text { Яка атмосфрера переважає у Вашому колективі? «1» } \\
\text { відповідає за нездорову, нетовариську атмоссреру, } \\
\text { «9»- атмоссреру взаєморозуміння, взаємної поваги. }\end{array}$ & 8 & 9 & 3 \\
\hline & Всього: & 40 & 17 & 3 \\
\hline \multicolumn{5}{|c|}{ Середня оцінка становить 0.6 (E +16, E 4) } \\
\hline \multicolumn{5}{|c|}{ Когнітивний компонент } \\
\hline $9 . \mathrm{a}$ & $\begin{array}{l}\text { Як вам здається, могли б Ви дати повну характерис- } \\
\text { тику ділових якостей більшості членів колективу? }\end{array}$ & 17 & 2 & 1 \\
\hline 9.6 & $\begin{array}{l}\text { Як Вам здається, могли б Ви дати повну характерис- } \\
\text { тику особистих якостей більшості членів колективу? }\end{array}$ & 14 & 5 & 1 \\
\hline 11. & $\begin{array}{l}\text { Могли б Ви з упевненістю сказати про більшість членів } \\
\text { колективу, з ким вони охоче спілкуються з ділових } \\
\text { питань? }\end{array}$ & 12 & 6 & 2 \\
\hline & Всього: & 43 & 13 & 4 \\
\hline \multicolumn{5}{|c|}{ Середня оцінка становить $0.5(\mathrm{~K}+15, \mathrm{~K} \sim 4, \mathrm{~K}-1)$} \\
\hline \multicolumn{5}{|c|}{ Поведінковий компонент } \\
\hline 7. & $\begin{array}{l}\text { Чи вважаєте Ви, що було б добре, якби члени Вашого } \\
\text { колективу жили близько одне від одного? }\end{array}$ & 5 & 13 & 2 \\
\hline 10. & $\begin{array}{l}\text { Якби у Вас була можливість провести відпустку разом } \\
\text { із членами Вашого колективу, як би Ви до цього поста- } \\
\text { вились? }\end{array}$ & 8 & 10 & 2 \\
\hline \multirow[t]{2}{*}{13.} & $\begin{array}{l}\text { 13. Як Ви думаєте, якби Ви вийшли на пенсію чи довго } \\
\text { не працювали з якоїсь причини, прагнули б зустріча- } \\
\text { тись із членами Вашого колективу? }\end{array}$ & 15 & 5 & \\
\hline & Всього: & 28 & 28 & 4 \\
\hline \multicolumn{5}{|c|}{ Середня оцінка становить $0.1(П+11, \Pi \sim 9)$} \\
\hline
\end{tabular}


в цілому з урахуванням емоційного, когнітивного та поведінкового компонентів. Певне співвідношення оцінок цих компонентів дозволяє схарактеризувати стан соціально-психологічного клімату колективу. Також під час діагностики визначався індекс групової оцінки праці, стан матеріальнотехнічного забезпечення, рівномірність навчального, наукового, організаційного навантаження, розмір заробітної плати, санітарно-гігієнічні умови, відносини 3 керівником, можливість підвищення кваліфрікації, різноманітність роботи, рівень організації освітнього процесу, ступінь впливу керівника на справи в колективі. Аналіз цих оцінок дозволив визначити стан соціально-психологічного клімату колективу і виявити моменти, які потребують корекції. Отримані результати діагностики представлено в таблиці 1.

Дані таблиці дозволяють визначити соціальнопсихологічний клімат колективу як позитивний. Поведінковий компонент, що визначає якісний бік міжособистісних стосунків, $€$ невизначеним, що свідчить про те, що керівнику слід звернути увагу на прогалини у взаємостосунках членів колективу.

3 метою визначення офріційної та неофіційної структури реципієнти в анонімному анкетуванні відповіли на питання «Хто з членів колективу користується найбільшою повагою в інших? Назвіть одне або два прізвища». Відповіді на питання дали змогу проаналізувати співвідношення офріційної і неофріційної структури науковопедагогічного колективу, тобто співвідношення керівництва і лідерства. На рис. 1 узагальнено
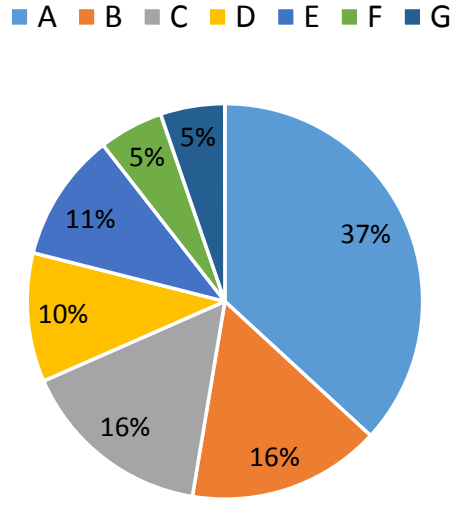

Рис. 1. Співвідношення офіційної та неофіційної структури науково-педагогічного колективу

представлено отримані результати визначення неофіційного лідера (3 метою анонімності прізвища членів колективу позначено латинськими літерами).

Результати діагностики засвідчили, що завідувача кафедри (А) визнано неофіційним лідером науково-педагогічного колективу кафедри. Отже, офріційним та неофіційним лідером $€$ керівник авторитетний член колективу.

3 метою визначення особистісних якостей керівника респонденти визначали його особистісні та ділові якості: доброзичливість, справедливість здатність розбиратись у людях, товариськість, чуйність, вимогливість, турбота про людей, профресійні знання, суспільна активність, працьовитість. Оцінювання найбільш розвинених якостей

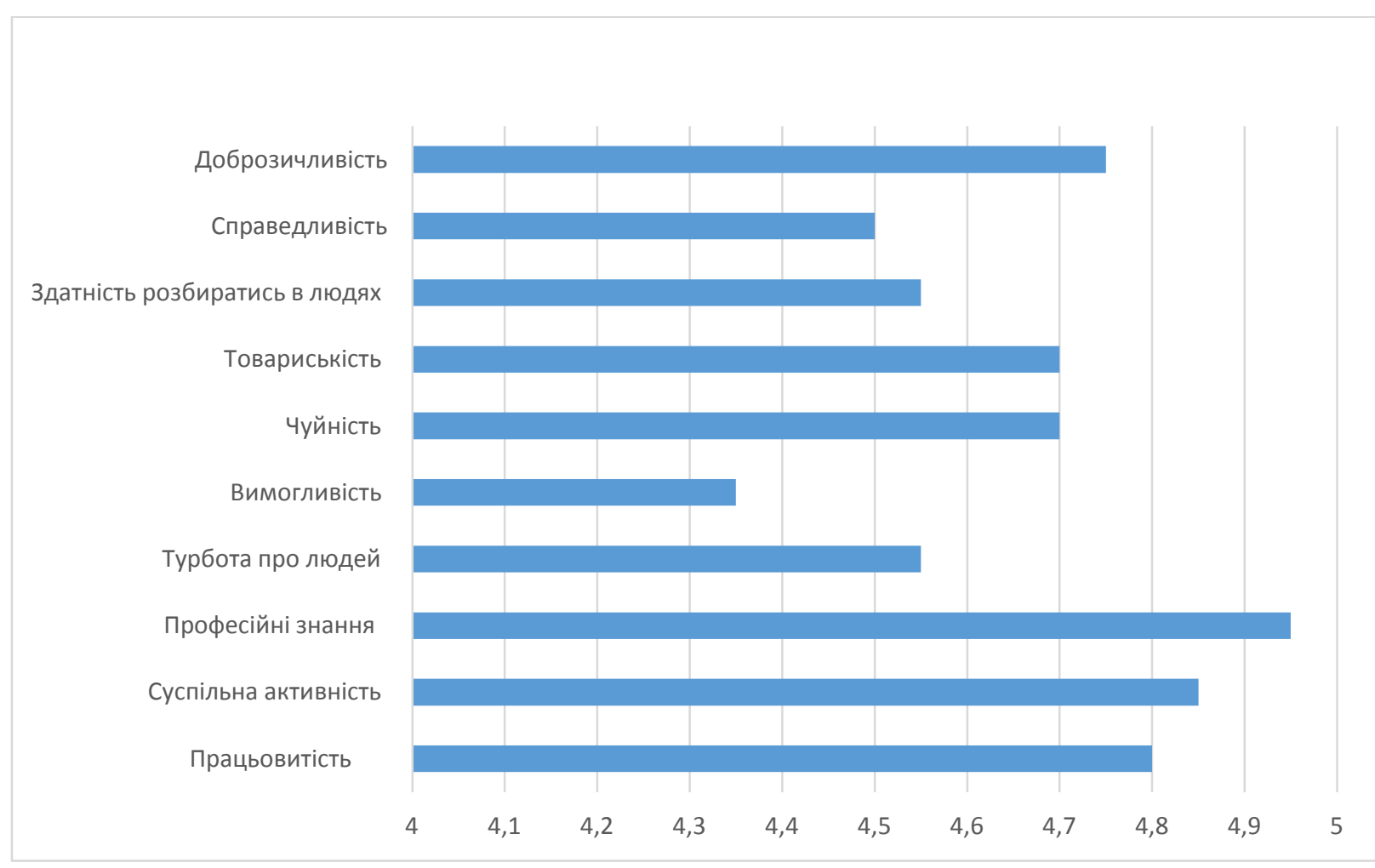

Рис. 2. Характеристика особистісних якостей керівника 
керівника відбувалося за визначенням середнього показника кожної якості. Отримані результати представлено на рис. 2. Отже, результати відповідей реципієнтів засвідчили, що підлеглі вважають свого керівника компетентною, доброзичливою, суспільно активною, товариською та чуйною людиною.

За результатами діагностики визначено індекс групової оцінки праці, які представлено в таблиці 2.

Отримані результати дали можливість виявити так звані вузькі місця, якими стали розмір заробітної плати та стан матеріально-технічного забезпечення освітнього процесу.

Результати дослідження показали, що загалом соціально-психологічний клімат науково-педагогічного колективу кафредри сприятливий, у колективі злагоджені міжособистісні відносини, але немає повної взаємодовіри та дружніх стосунків поза межами робочого часу.
3 метою визначення впливу стилю керівництва на стан соціально-психологічного клімату науково-педагогічного колективу кафредри проведено тестування за методикою «Пульсар» Л. Почебута, що передбачало діагностику якостей науково-педагогічного колективу: готовність до діяльності (готовність колективу вирішувати поставлені задачі); спрямованість (усвідомлення цілей, інтересів, норм, способів і засобів діяльності, критеріїв оцінки результатів); організованість (розподіл ролей і статусів у колективі, наявність формальної і неформальної структури); активність (здатність здійснювати суспільно значущу діяльність, міра реалізації фрізичного та інтелектуального потенціалу її членів); згуртованість (стійкість і єдність міжособистісних взаємовідносин і взаємодій, забезпечення стабільності і спадкоємності); інтегративність (узгодженість внутрішньогрупових процесів); ресрерентність

Результати діагностики індексу групової оцінки праці

\begin{tabular}{|c|l|c|c|c|}
\hline \multirow{2}{*}{ № питання } & \multicolumn{1}{|c|}{ Питання } & $\begin{array}{c}\text { Позитивна } \\
\text { оцінка }\end{array}$ & $\begin{array}{c}\text { Невизначена } \\
\text { оцінка }\end{array}$ & $\begin{array}{c}\text { Негативна } \\
\text { оцінка }\end{array}$ \\
\hline 14.1 & Стан матеріальної бази & 11 & 5 & 4 \\
\hline 14.2 & Рівномірність забезпечення роботою & 16 & 1 & 3 \\
\hline 14.3 & Розмір заробітної плати & 12 & 3 & 5 \\
\hline 14.4 & Санітарно-гігієнічні умови & 18 & 2 & 0 \\
\hline 14.5 & Можливість підвищення квалісікації & 17 & 2 & 1 \\
\hline 14.6 & Різноманітність роботи & 19 & 0 & 1 \\
\hline 15. & Рівень організації роботи & 20 & 0 & \\
\hline 16. & Ступінь впливу керівника на справи в колективі & 18 & 0 & 2 \\
\hline
\end{tabular}

Таблиця 3

Визначення впливу стилю керівництва на стан соціально-психологічного клімату науково-педагогічного колективу кафедри

\begin{tabular}{|c|c|c|}
\hline Якості & Сер. оц. & Характеристика колективу \\
\hline $\begin{array}{l}\text { Підготовленість } \\
\text { до діяльності }\end{array}$ & 9 балів & $\begin{array}{l}\text { Більшість членів колективу мають гарну просресійну підготовку, прагнуть підви- } \\
\text { щити свою кваліфрікацію, намагаються застосовувати свої знання на практиці. }\end{array}$ \\
\hline Спрямованість & 9 балів & $\begin{array}{l}\text { Перед колективом стоїть спільна задача. Кожен член колективу намагається } \\
\text { задовольнити свої інтереси в межах вирішення спільної групової задачі. } \\
\text { У колективі вироблені взаємоприйняті норми поводження. }\end{array}$ \\
\hline Організованість & 8 балів & $\begin{array}{l}\text { Колектив часто намагається самостійно організувати свою роботу, але це не } \\
\text { завжди виходить ефективно. Керівник нечітко уявляє собі можливості кожного. }\end{array}$ \\
\hline Активність & 8 балів & $\begin{array}{l}\text { Більшість членів колективу люди енергійні, зацікавлені в ефективній роботі. } \\
\text { Коли потрібно зробити корисну для всіх справу, багато членів колективу активно } \\
\text { беруть участь у спільній роботі, допомагаючи одне одному. }\end{array}$ \\
\hline Згуртованість & 8 балів & $\begin{array}{l}\text { Більшість членів колективу намагаються справедливо ставитись одне до } \\
\text { одного, допомогти неосвіченим, підтримати їх, зорієнтувати в нових умовах. } \\
\text { У важких випадках колектив тимчасово об'єднується, відчувається емоційна } \\
\text { підтримка. }\end{array}$ \\
\hline Інтегративність & 8 балів & $\begin{array}{l}\text { За необхідності виробити важливе рішення всі члени колективу намагаються } \\
\text { активно брати участь у процесі його вироблення і прийняття. Враховуються } \\
\text { думки більшості членів колективу. Рішення приймається шляхом спільного голо- } \\
\text { сування. }\end{array}$ \\
\hline Ресрерентність & 9 балів & $\begin{array}{l}\text { У колективі є різні люди: гарні і погані, дуже симпатичні і малопривабливі. Досяг- } \\
\text { нення і невдачі всього колективу щиро переживаються його членами. У колек- } \\
\text { тиві у всіх гарне рівне ставлення. }\end{array}$ \\
\hline & & Середня арифметична оцінка - 8,43 балів \\
\hline
\end{tabular}


(членство у колективі є цінним і значущим). Оцінка кожної якості уможливила визначення рівня розвитку (зрілості) науково-педагогічного колективу кафредри: зріла група: згуртована, працездатна і надійна; достатньо зріла група: здатна виконувати виробничі завдання; недостатньо зріла група: не завжди здатна ефективно впоратися $з$ поставленими завданнями; незріла група: велика ймовірність того, що вона не впорається з поставленими завданнями. На підставі аналізу відповідей визначено стан науково-педагогічного колективу, які представлено у таблиці 3.

Результати засвідчили, що науково-педагогічний колектив кафедри оцінено як достатньо зрілий, здатний виконувати поставлені завдання. Зрілість науково-педагогічного колективу кафедри підтверджує стаж роботи педагогів у цьому колективі, адже переважна більшість членів колективу (17 із 20) працює понад 5 років на кафедрі. Це свідчить про те, що колектив $є$ сорормованим.

На основі отриманих даних встановлено, що завідувач кафедри має позитивні особистісні характеристики: визначеність, усвідомленість, цілеспрямованість, вибірковість, тактовність, дієвість, вимогливість, критичність, відповідальність. Пріоритетним стилем керівництва завідуючого кафедри є демократичний.

Отримані результати дали змогу оцінити науково-педагогічний колектив кафедри як достатньо зрілий, здатний виконувати поставлені завдання. Соціально-психологічний клімат науково-педагогічного колективу визначено як сприятливий. Керівник є офріційним лідером колективу кафедри 3 позитивними особистісними характеристиками. Колектив є сорормованим, але має певні прогалини у взаєминах між членами колективу, у зв'язку з чим керівнику необхідно створити умови для зближення членів колективу.

Встановлено, що певні чинники макросередовища негативно впливають на соціально-психологічний клімат науково-педагогічного колективу кафедри, науково-педагогічні працівники недостатньо задоволені матеріально-технічним забезпеченням та розміром заробітної плати.

Отже, в результаті дослідження встановлено, що соціально-психологічний клімат науково-педагогічного колективу кафедри впливає на продуктивність та якість праці, міжособистісні взаємовідносини, рівень конфліктності у колективі, ступінь задоволеності працею та її умовами і залежить від певних чинників, засадничими з яких є стиль керівництва, який у свою чергу залежить від особистісних характеристик керівника і від управлінської ситуації. Саме поведінка керівника у колективі, його стиль керівництва безпосередньо впливає на емоційний стан працівників, відносини у колективі та стан соціально-психологічного клімату науковопедагогічного колективу кафедри.
Висновки. За результатами дослідження стану соціально-психологічного клімату колективу на прикладі науково-педагогічного колективу однієї 3 кафедр Вінницького державного педагогічного університету ім. М. Коцюбинського та впливі на нього стилю управлінської діяльності керівника з'ясовано, що проблема фрормування та підтримання сприятливого соціально-психологічного клімату колективу пов'язана зі складністю досліджуваного френомену, що включає комплекс характеристик, який неможливо визначити за єдиним показником.

Результати дослідження довели взаємозв'язок стилю керівництва та стану соціально-психологічного клімату колективу. Соціально-психологічний клімат відображає якісний бік міжособистісних відносин членів колективу. Стиль керівництва, відносини між членами колективу є одними із найголовніших чинників, що впливають на якість та продуктивність праці та взаємини між членами колективу. За результатами дослідження встановлено, що науково-педагогічний колектив кафедри $\epsilon$ сорормованим, але має певні прогалини у взаємостосунках членів колективу. У зв'язку 3 цим керівнику необхідно створити умови для зближення членів науково-педагогічного колективу.

Перспектива подальшого дослідження передбачає розробку практичних рекомендацій керівникам структурних підрозділів закладу вищої освіти щодо формування та підтримання сприятливого клімату науково-педагогічного колективу.

\section{БІБЛІОГРАФІЧНИЙ СПИСОК:}

1. Goleman D. Leadership That Gets Results // Harvard Business Review. 2000. March - April.

2. Аникеева Н.П. Психологический климат в коллективе. / Н.П. Аникеева. М. : Просвещение, 1991. $200 \mathrm{c}$

3. Виноградова Г.А. Нравственно-психологический климат в педагогическом коллективе как фрактор становления мастерства учителя : дис. ... канд. пед. наук: 13.00.01 «Общая педагогика, история педагогики и образования» / Г.А. Виноградова. СПб, 1992. 16 c.

4. Виноградова Г.А. Теоретические основы формирования нравственно-психологического климата в профессионально-педагогических коллективах : дис. ... д-ра психол. наук: спец. 19.00.07 «Педагогическая психология» / Г.А. Виноградова; СПб. гос. ун-т. СПб., 1998. 345 с.

5. Джонсон Д.В. Соціальна психологія: тренінг міжособистісного спілкування / Д.В. Джонсон; пер. 3 англ. В. Хомика. К. : Видавничий дім «КМ Академія», 2003. 288 с.

6. Ермолаева Е.А. Влияние стиля руководства директора на социально-психологическую атмосферу в педагогическом коллективе : автореф. дис. ... канд. пед. наук: спец: 13.00.01 «Общая педагогика, история педагогики и образования» / Е.А. Ермолаева. Л. : Ленингр. гос. ун-т им. А.А. Жданова, 1972. 19 c. 
7. Карамушка Л.М. Психологічні основи управління в системі середньої освіти : навч. посіб. I Л.М. Карамушка. К. : ІЗМН, 1997. 180 с.

8. Коломінський Н.Л. Психологія менеджменту в освіті (соціально-психологічний аспект). Монографрія. / Н.Л. Коломінський. К. : МАУП, 2000. 286 с.

9. Мешко О.І. Формування готовності шкільних психологів до створення психологічного клімату в педагогічному колективі : автореф. дис. ... канд. психол. наук: спец. 19.00.07 «Педагогічна та вікова психологія» / О.І. Мешко; УдпУ ім. М.П. Драгоманова. К., 1995. 24 с.

10. Молочко М.В. Формування соціально-психологічного клімату в педагогічному колективі / М.В. Молочко // Рідна школа. 2004. № 4. С. 52-53.

11. Мансуров Н.С. Морально-психологический климат и его изучение / Н.С. Мансуров. М., 2004. 235 с.

12. Почебут Л.Г. Организация социальная психология : учебное пособие / Л.Г. Почебут, В.А. Чикер. СПб : Речь, 2002. 298 с.
13.Про затвердження Положення про освітньо-квалісрікаційні рівні (ступеневу освіту) (чинна редакція) [Електронний ресурс]. - Режим доступу: h t t p s://zakon.rada.gov.ua/laws/show / 65-98-\%D0\%Bf.

14. Семиченко В.А. Психологія педагогічної діяльності : навч. пос. / В.А. Семиченко. К. : Вища школа, 2004. 335 c.

15. Туріщева Л.В. Вивчення особистості школяра і педагога / Л.В. Туріщева, О.В. Гончаренко. Харків : Вид. група «Основа», 2007. 144 с.

16.Шакуров Р.X. Социально-психологические основы управления: руководитель и педагогический коллектив / Р.Х. Шакуров. Москва : Просвещение, 1990. 208 C.

17.Шепель В.М. Управленческая психология / В.М. Шепель. М. : Экономика, 1984. 246 с.

18. Яцура В.В. Менеджмент : навчальний посібник / В.В. Яцура, О.П. Жук. Львів : Видавничий центр ЛНУ імені Івана Франка, 2008. 444 С. 